\title{
Getting the chemicals right: Toward characterizing toxicity and ecotoxicity impacts of inorganic substances
}

\author{
Kirchhübel, Nienke; Fantke, Peter
}

Published in:

Journal of Cleaner Production

Link to article, DOI:

10.1016/j.jclepro.2019.04.204

Publication date:

2019

Document Version

Peer reviewed version

Link back to DTU Orbit

Citation (APA):

Kirchhübel, N., \& Fantke, P. (2019). Getting the chemicals right: Toward characterizing toxicity and ecotoxicity impacts of inorganic substances. Journal of Cleaner Production, 227, 554-565.

https://doi.org/10.1016/j.jclepro.2019.04.204

\section{General rights}

Copyright and moral rights for the publications made accessible in the public portal are retained by the authors and/or other copyright owners and it is a condition of accessing publications that users recognise and abide by the legal requirements associated with these rights.

- Users may download and print one copy of any publication from the public portal for the purpose of private study or research.

- You may not further distribute the material or use it for any profit-making activity or commercial gain

- You may freely distribute the URL identifying the publication in the public portal

If you believe that this document breaches copyright please contact us providing details, and we will remove access to the work immediately and investigate your claim. 


\section{Accepted Manuscript}

Getting the chemicals right: Toward characterizing toxicity and ecotoxicity impacts of inorganic substances

Nienke Kirchhübel, Peter Fantke

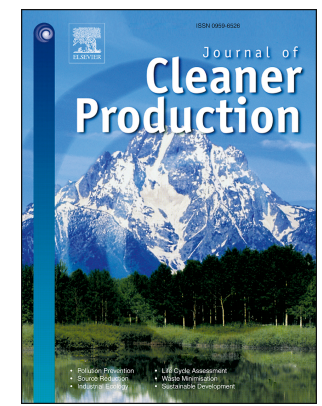

PII:

S0959-6526(19)31291-0

DOI:

https://doi.org/10.1016/j.jclepro.2019.04.204

Reference: JCLP 16560

To appear in: Journal of Cleaner Production

Received Date: 10 January 2019

Revised Date: 3 April 2019

Accepted Date: 17 April 2019

Please cite this article as: Kirchhübel N, Fantke P, Getting the chemicals right: Toward characterizing toxicity and ecotoxicity impacts of inorganic substances, Journal of Cleaner Production (2019), doi: https://doi.org/10.1016/j.jclepro.2019.04.204.

This is a PDF file of an unedited manuscript that has been accepted for publication. As a service to our customers we are providing this early version of the manuscript. The manuscript will undergo copyediting, typesetting, and review of the resulting proof before it is published in its final form. Please note that during the production process errors may be discovered which could affect the content, and all legal disclaimers that apply to the journal pertain. 
1 Getting the chemicals right: Toward characterizing toxicity and ecotoxicity

2 impacts of inorganic substances

3

4 Nienke Kirchhübel ${ }^{\dagger}$, Peter Fantke ${ }^{\dagger *}$

5

6 'Quantitative Sustainability Assessment Division, Department of Management Engineering,

7 Technical University of Denmark, Produktionstorvet 424, 2800 Kgs. Lyngby, Denmark 8

9 "Corresponding author: Tel.: +45 45254452, fax: +45 45933435. E-mail: pefan@dtu.dk 10 
Abstract

Characterizing human and ecological exposure and toxicity impacts from emissions of chemical substances along life cycles of consumer products and industrial processes is an important building block in various decision support frameworks. Various products and processes involve the use of inorganic substances, such as inorganic salts, acids, and bases. However, except selected metal ions, inorganic substances are currently not included in any existing chemical toxicity characterization framework, leaving an important gap unaddressed in current assessments of environmental performance of products and services, chemical substitution, and substance prioritization. To address this gap, we provide initial guidance for identifying and characterizing toxicity-related impacts of currently unconsidered inorganic substances. Starting from a chemical classification of inorganic substances, we determine both the economic and environmental relevance of inorganic compounds currently registered under the European REACH regulation, and combine both to identify substances that should be prioritized for future toxicity characterization. Further, we provide an overview of current challenges and outline possible ways forward toward incorporating inorganic substances into toxicity characterization models. We identified approximately 90 inorganic high-priority substances that are both of high economic as well as of high environmental relevance. Current characterization methods need to be adapted and extended to account for the complex reaction chemistry and data limitations for effect quantification of inorganic substances. Future research is required that targets the inorganic reaction chemistries and that overcomes current data limitations. This will ultimately lead to a more comprehensive decision support in line with the global sustainability agenda set for chemicals management.

Keywords: Life cycle impact assessment, Inorganics, Environmental Fate, Human and 


\section{Introduction}

Characterizing toxicity impacts on humans and ecosystems from chemical exposure is an important building block of different decision support frameworks including product life cycle assessment and chemical footprinting, chemical substitution and chemical alternatives assessment, high-throughput chemical risk screening, and managing chemicals in the circular economy (Wetmore et al., 2012; Shin et al., 2015; Fantke et al., 2016b; Greggs et al., 2018; Tarasova et al., 2018; Fantke and Illner, 2019; Ring et al., 2019). Toxicity characterization thereby builds on quantitatively describing a substance's entire impact pathway including environmental fate (distribution among environmental media and phases), exposure of humans and ecosystems, and toxicological effects (Hauschild and Huijbregts, 2015). While quantified toxicity-related impact factors for approximately 3,000 organic substances and several specific metal ions are already included in existing characterization models (Rosenbaum et al., 2008; Wambaugh et al., 2013), most of the tens to thousands of substances in commercial use worldwide still remain to be characterized for potential exposures and toxicity impacts (Fantke et al., 2015, 2018b; Hauschild and Huijbregts, 2015). However, to provide decision support based on a comprehensive evaluation of chemical emissions and exposures in the various consumer and industrial product applications, all relevant substances need to be considered in toxicity characterization models.

Various economic production processes involve the use of a diversity of substance classes that are currently not addressed in chemical toxicity characterization. Among these are distinct chemical elements and various inorganic compounds, such as inorganic salts, acids, and bases. Inorganic substances, such as for example sodium sulfate decahydrate, sodium hydroxide, sodium carbonate, titanium(IV)oxide, and sodium hydrosulfite, are used in large quantities in different economic sectors, for example in the textile industry, in the personal care sector, and in the building and construction industry (Swedish Chemicals Agency, 2014; National Library of Medicine, 2018). However, these and most other marketed inorganic substances are presently missing in existing emission inventory databases, and methods are currently lacking that are able to characterize inorganic substances in terms of their potential exposures and toxicity impacts. Some specific inorganic substance groups are included in methods for characterizing climate change related impacts (e.g. sulfur hexafluoride, carbon dioxide, and other greenhouse gases) and eutrophication related impacts (e.g. phosphorus pentoxide, nitrogen dioxide, and other eutrophying substances), whereas available toxicity characterization models do not currently consider inorganic substances beyond some selected 
metal ions (Pennington et al., 2005; Rosenbaum et al., 2008; van Zelm et al., 2009; Iacovidou et al., 2017).

Physicochemical properties governing environmental fate, exposure, and toxicity effects differ widely between substances (Strempel et al., 2012). Often, structurally similar substances also show similar properties and health effects (Rabesandratana, 2016) and can be grouped in terms of these properties (Grimm et al., 2016). With respect to impact characterization, various chemical substance groups need to be distinguished in modelling approaches in order to account for their distinct environmental distribution mechanisms, exposure patterns and effects, including organic substances, metals, nanomaterials, ionizing substances, and inorganic substances. In the following, we summarize main characteristics of the different substance groups, in order to better understand how inorganic substances are different from other substance groups.

Briefly, organic substances are compounds containing a significant amount of hydrogen bound carbon, usually bound to oxygen, nitrogen, halogens, and some other elements building functional groups. However, a small number of carbon-containing compounds is traditionally considered inorganic, such as carbides, carbonates, carbon oxides, and cyanides. Models assessing the environmental fate of organic substances basically build on phase partitioning principles and use parameters like the $n$-octanol/water partitioning coefficient to estimate the distribution of a substance between different environmental media (e.g. air, soil, water) or phases (e.g. soil gas, soil solids) (Schwarzenbach et al., 2016). Assessing exposure to organic substances is usually linked to using bioconcentration factors and bioaccumulation factors. Various organic substances are already included in characterization models, usually when enough data for assessing fate, exposure and effects are available. Expanding the coverage of organic substances that are currently missing in existing characterization models is mainly constrained by the lack of appropriate data for degradation, bioaccumulation, or human and ecosystem toxicity effects (Fantke et al., 2016a; Müller et al., 2017). In contrast to organic substances, the environmental fate of metal ions is usually modelled as function of equilibrium-based metal speciation (Landner and Reuther, 2004). Exposure to metal ions depends on the metals' bioavailability, which is controlled mainly by $\mathrm{pH}$-dependent dissolution and complexation of the ions with dissolved organic matter, which can be described with the chronic biotic ligand model and the free ion activity model (Dong et al., 2014).

To build characterization models for addressing inorganic substances, approaches used for modeling organic substances or metal ions are not applicable and instead, a set of distinct 
physical, chemical and biological factors will need to be considered. Physical factors refer to characteristics of the compartment a substance is emitted or transferred to (e.g. soil organic matter content, air temperature, water salinity), of which some aspects are also relevant for fate of organic substances and metals. Chemical factors driving fate of inorganic substances involve chemical reaction kinetics and dynamics, such as hydration, hydrolyzation, or $\mathrm{pH}$ dependent reactions, which can be very complex. As biological factors, biotransformation conditions need to be considered, as the fate of an inorganic substance might be completely different in anaerobic conditions compared to aerobic conditions. For example, reduced inorganic substances, such as hydrogen sulfide, are microbially oxidized only under aerobic conditions to gain energy (Rabus et al., 2013). Physicochemical properties relevant for characterizing inorganic substances include, amongst others, activity coefficients, equilibrium constants, phase-specific heat conductivity and heat capacity, (electro-)chemical potential, and water solubility (Holleman et al., 2007; Rumble 2018). Relevant fate, exposure and effect aspects are well-described for metal compounds in existing risk assessment methods (Verougstraete, 2018), while such information in compiled form is less available for nonmetal inorganic compounds. In order to incorporate missing substances in toxicity characterization frameworks and identify how they should be characterized, a classification scheme is needed that can help providing the necessary overview and identifying patterns of common physicochemical properties that can be used to determine similar environmental pathways and mechanisms that need to be considered to define how the fate, exposure and effects of this substance can be adequately modeled.

In the history of chemistry and environmental chemistry, chemical substances have been classified according to various criteria. These include grouping of elements in the periodic table, ordered by their atomic number, electron configurations, and recurring chemical properties, into main- and sub-groups, such as different metal speciations, nonmetals,

130 halogens, noble gases, etc. (Holleman et al., 2007). More complex chemical substances have

131 been grouped according to their molecular structure (e.g., hydrocarbons, acids), uses (e.g.,

132 pesticides, disinfectants), physicochemical properties (e.g., volatile organic compounds, 133 nanomaterials), radiological properties (e.g., radioactive materials), or other factors

134 (Holleman et al., 2007; Hauschild and Huijbregts, 2015; Schwarzenbach et al., 2016).

135 However, for prioritizing substances for their inclusion in toxicity characterization, substance 136 classification (to identify "how" to model a substance) must be complemented by criteria for 137 economic and environmental relevance (to identify "which" substances to model in priority). 
138 Such a combined classification and prioritization scheme, however, is currently missing but urgently needed to focus future chemicals characterization and management efforts.

In response to this need, it is the goal of the present study to provide an overview of aspects that need to be considered for building methods and models to characterize toxicityrelated impacts of a wide range of currently unconsidered compounds in comparative chemical assessment frameworks with specific focus on inorganic substances. To achieve this goal, we focus on three specific objectives: (a) to classify chemical substances as input for identifying substances that are potentially relevant for different assessment frameworks with focus on the class of inorganic compounds that are missing in existing toxicity characterization models; (b) to specify the economic and environmental relevance of inorganic compounds and combine both to identify substances that should be prioritized for future toxicity characterization; and (c) to provide an overview of the current challenges of characterizing toxicity-related impacts of inorganic substances on humans and ecosystems, and to outline possible ways forward toward incorporating inorganic substances into toxicity characterization models in a set of recommendations.

\section{Methods}

To identify important inorganic substance groups that are currently missing in toxicity characterization models, the relevance of substances in terms of economic use as well as in terms of potential toxicity-related environmental impacts has to be understood. First, we determine which inorganic substances are used to what extent in currently marketed consumer and industry products as well as in industrial processes. All economically relevant substances among these are further assessed with respect to regulatory criteria to determine their environmental relevance. The chosen selection criteria are summarized in Table 1 and detailed in the following.

Table 1: Selection criteria for identifying inorganic substances relevant for toxicity characterization.

\begin{tabular}{lll}
\hline & Selection criteria & Example \\
\hline $\begin{array}{l}\text { Substance } \\
\text { information }\end{array}$ & $\begin{array}{l}\text { - Substance is registered under the European } \\
\text { REACH Regulation }\end{array}$ & $\begin{array}{l}\text { Diammonium peroxodisulfate } \\
\text { (CAS: 7727-54-0): registered under }\end{array}$ \\
& $\begin{array}{l}\text { Type of substance origin is "inorganic" (either } \\
\text { as originally stated or corrected where needed) }\end{array}$ & $\begin{array}{l}\text { REACH (dossier number 14389), } \\
\text { with Type of substance origin: } \\
\text { "inorganic" }\end{array}$ \\
$\begin{array}{lll}\text { Economic } \\
\text { relevance }\end{array}$ & $\begin{array}{l}\text { Substance is manufactured and/or imported in } \\
\text { the European Economic Area in volume of at } \\
\text { least 1,000 tonnes per year }\end{array}$ & $\begin{array}{l}\text { Diammonium peroxodisulfate } \\
\text { (CAS: 7727-54-0): manufactured } \\
\text { and/or imported in the European }\end{array}$ \\
\hline
\end{tabular}




\section{Example}

Economic Area in 10,000 to 100,000 tonnes per year

Environmental • Substance has information about human health relevance hazard according to the European CLP

Diammonium peroxodisulfate (CAS: 7727-54-0): acute toxicity Regulation (acute toxicity, aspiratory toxicity, germ cell mutagenicity, carcinogenicity, class 4 , and specific target organ toxicity from singe exposure class 3 reproductive toxicity, specific target organ toxicity)

- Substance has information about environmental hazard according to the European CLP Regulation (acute ecotoxicity to aquatic organisms, chronic ecotoxicity to aquatic organisms)

\subsection{Information on chemical substances}

We retrieved and reviewed data for 14814 substances registered as of 15/01/2018 under the Registration, Evaluation, Authorisation and Restriction of Chemicals (REACH) Regulation (European Commission, 2006). All substances manufactured in or imported to the European Economic Area (EEA) with an annual volume above one tonne have to be registered. Exemptions from registration under this particular regulation are described in its Annex V. Exemptions include radioactive substances, non-isolated intermediates, transported hazardous substances, waste, substances under customs supervision, substances used in the interest of defense and covered by national exemptions, substances used in biocides and plant protection products, substances used in food and feedstuffs as flavoring, substances used in medicinal products, natural, not chemically modified substances, substances used in research and development, substances already registered, then exported from and re-imported into the EEA, and substances already registered and recovered through a waste recovery process.

180 For more than one third $(n=5135)$ of the 14814 registered substances, the origin (inorganic, organic, organometallic, element, or confidential/unknown) was either not provided, required harmonization (e.g. nickel bis(2-ethylhexanoate) registered as "inorganic, other: metallic salt with organic ligand" was assigned to be an "organometallic" substance), or incorrect (e.g. (2hydroxyethyl)ammonium nitrate registered as "inorganic" was corrected to be an "organic" substance). We revised the origin of all 14814 substances using additional substance information, such as IUPAC name or molecular formula. If substance information to verify the origin was missing, the origin given in the original data was adopted. All registered inorganic compounds and elements were further classified in more refined levels according to their shared physical and chemical properties and molecular composition. 


\subsection{Assessing economic relevance}

For evaluating the economic relevance of registered substances, the cleaned data for the inorganic compounds and elements were ranked according to reported market data, such as annual production volume within and/or annual import volume into the EEA. The threshold for identifying a substance as economically relevant was set to 1000 tonnes per year (Table 1), acknowledging that market prices would be a better metric due to highly varying market values across substances. However, substance-specific market prices are only available via commercial market statistics reports, such as the global production, trade and price statistics for the inorganic substance hydrogen cyanide (Research and Markets, 2018). Data extracted from such reports can usually not be redistributed.

\subsection{Assessing environmental relevance}

To subsequently rank registered inorganic substances in terms of their environmental relevance, we used data on the classification, labelling and packaging (CLP) of substances and mixtures Regulation (European Commission, 2008). Main focus was set on the formal hazard classes of the CLP Regulation (Table 1), which cover both environmental and human health hazards. The human health hazard classes "acute toxicity", "aspiratory toxicity", "germ cell mutagenicity", "carcinogenicity", "reproductive toxicity", and "specific target organ toxicity" were considered for the evaluation of the relevance regarding human toxicity. The environmental hazard classes acute and chronic "ecotoxicity to aquatic organisms" were considered for the evaluation of the relevance regarding ecotoxicity. We acknowledge that hazard alone cannot replace a full multimedia fate, multi-pathway exposure and toxicity analysis, where each substance might have different fate and exposure distribution pathways, and contribute to different modes of toxic action commonly assessed using effect concentrations (ecotoxicity) and effective doses (human toxicity) (Fantke et al., 2015, 2018b; Hauschild and Huijbregts, 2015). However, we did not use additional criteria for our initial screening of inorganic substances for their potential environmental relevance, but instead use the screening criteria set out under the CLP Regulation are based on a set of internationally agreed, standardized and harmonized hazard criteria as first proxy. We thereby note that the current REACH substance registration requirements may not always provide sufficient information to conclude on specific substance classification criteria, such as "carcinogenicity" (Woutersen et al., 2018).

Results from the chemical classification of substance groups, from the environmental and from the economic relevance evaluation were finally combined, where classification results 
were used as filter (only considering inorganic substances in the end), and where environmental and economic relevance results were used to rank substances according to decreasing relevance. This way, the combined results from our analysis can be used as input to provide recommendations for developing a quantitative framework for toxicity characterization of inorganic substances that is consistent with existing approaches. To understand to what extent existing characterization models consider toxicity impacts, a widely used toxicity characterization model (Rosenbaum et al., 2008) was analyzed in terms of how the environmental fate, exposure, and effects of different substance groups are currently addressed, and how the model can potentially be extended to also consider toxicity-related impacts of inorganic substances. As a complementary element, life cycle emission inventory databases were examined to identify inorganic substance groups that are already characterized in terms of impacts associated with different impact categories. Finally, reaction pathways and relevant data sources specific for toxicity characterization of inorganic substances were explored to provide additional guidance for future research.

\section{Results and Discussion}

\subsection{Classification of chemical substances}

The classification of chemical substances as basis for developing modeling approaches for toxicity characterization has to be aligned with their shared physical and chemical properties distinguishing major substance groups. This is important, since substance groups at different levels of categorization may have distinct data and process description requirements for adequately capturing their fate, exposure and effect mechanisms. Examples are organic, inorganic nonmetal, and inorganic metal compounds showing distinct reaction kinetics in the environment. As a result, we propose a chemical classification system that can be applied to categorize substance groups at various levels of refinement (Figure 1), as detailed in the following.

Chemical substances (first, non-refined level) can be differentiated according to our proposed classification scheme at six levels of refinement, starting with elements and compounds at the second level (most basic refinement of chemical substances). At the third level (further refining elements and compounds), elements can be categorized as elemental metals and elemental nonmetals, which can be distinguished into further sub-groups at higher levels of refinement depending on their chemical properties. An example is the distinction of metals into alkali, alkaline earth and a few more metal groups, where alkali metals differ from alkaline earth metals in their lower melting and boiling points - both measures of 
intermolecular bonding strength. This is due to differences in number of delocalized electrons per cation ( 1 for alkali and 2 for alkaline metals), which may influence how to model e.g. sorption behavior of these metal groups in soil (Chitra et al., 1999).

Compared to only 118 naturally occurring elements (e.g. iron or bromine) and 24 synthetic elements (e.g. americium mainly used in smoke detectors), compounds are the biggest group of chemical substances used in all industrial areas. Compounds are molecular composites and contain by definition two or more chemical elements (Holleman et al., 2007). In our classification scheme, compounds can at the third level of refinement be generally categorized as organic and inorganic compounds. Organic compounds, such as organic phosphate pesticides, perfluorinated alkylated substances, or organic solvents, are the largest share of chemical compounds registered under the REACH Regulation, with 30000-100000 industrially relevant substances worldwide. Existing toxicity models already characterize a few thousand compounds focusing on different organic compound groups. Characterizing organic compounds that are currently not considered is mostly constrained by missing physicochemical, bioaccumulation and toxicity effect data. While organic compounds are widely recognized in toxicity characterization, we focus in the present study on inorganic compounds (especially those that have potential economic and environmental relevance) as a compound class that is entirely missing in existing toxicity characterization approaches. Therefore, we do not further distinguish between the various groups of organic compounds at higher levels of refinement.

Inorganic compounds, a group covering approximately 100000 substances (Villars et al., 2017), of which several thousand are produced at commercial scales, can consist of nonmetal constituents and metal constituents. These can be further distinguished into sub-groups at higher levels of refinement (fourth and fifth level of refinement in Figure 1). At the sixth level of refinement, we divide between 8 different chemical substance types including three different bonds: 3 types of neutral molecules, characterized by covalent bonds (inorganic nonmetal, organometallic, and organic), 4 types of ionic compounds, characterized by ionic bonds (inorganic nonmetal, inorganic nonmetal-metal, organic-metal, and organic), and intermetallic compounds, characterized by metallic bonds. Complexes characterized by coordinate covalent bonds are for simplification included in the group of molecules. At the sixth level of refinement, we furthermore indicated by colored boxes that ionic compounds can refer to acids, bases, salts, or amphoters.

In existing characterization models, from an emission of an inorganic compound consisting of both, a metal and a nonmetal constituent $\left(\mathrm{IC}_{\mathrm{mnm}}\right)$, currently only the metal 
constituent (i.e. metal ion) is considered, whereas the nonmetal constituent of the compound is not characterized. This implies an important assumption, namely that only the metal constituent is seemingly responsible for the toxicity of the entire compound that is emitted. This is, however, not the case for several $\mathrm{IC}_{\mathrm{mnm}}$ compounds, such as for example metal cyanides, where not only the metal, but especially the nonmetal cyanide group is causing the high toxicity of these compounds (Redman and Santore, 2012). More generally, inorganic compounds containing the same metal constituent but combined with different nonmetal ions have widely differing physicochemical properties and related fate, exposure, and effect characteristics. An example are different compounds containing trivalent chromium, $\mathrm{Cr}(\mathrm{III})$, where chromium (III) chloride has an oral lethal dose (LD50) for rats of $440 \mathrm{mg} / \mathrm{kg}$ body weight (moderately toxic), chromium (III) nitrate has an LD50 of $3250 \mathrm{mg} / \mathrm{kg}$ body weight (less toxic), and chromium (III) oxide has an LD50 >15000 mg/kg body weight (much less toxic) (Egorova and Ananikov, 2017). Hence, it cannot be generalized that only the metal ion is driving human toxicity or ecotoxicity results, but also the nonmetal constituents need to be considered. Even in cases where it is evident that only the metal (or in other cases only the nonmetal) constituents are contributing to compound toxicity, usually the specific combination of metal ion and nonmetal ion governs large parts of the environmental partitioning and transport processes, as well as bioaccumulation and toxicity potentials. Finally, there is a group of 87 inorganic compounds that only consist of nonmetal, inorganic constituents, $\mathrm{IC}_{\mathrm{nm}}$, (sixth level of refinement in Figure 1), which are currently not considered in toxicity characterization models. $\mathrm{IC}_{\mathrm{nm}}$ include halogen compounds, such as chlorine dioxide used as oxidizing agent in the paper industry and in water treatment, and ammonium chloride used as nitrogen source in fertilizers, as flux in metal surface work and as dye in the textile and leather tanning industry.

Despite potential toxicological effects, inorganic substances can lead to other types of impacts, such as impacts on climate change, ionizing radiation, or eutrophication (Table 2). As an overview, we summarize in the following how inorganic substances are considered more generally in available characterization frameworks with respect to contributing to the wide range of environmental impacts. For that, we use as an example a commonly used life cycle impact assessment method. 
5

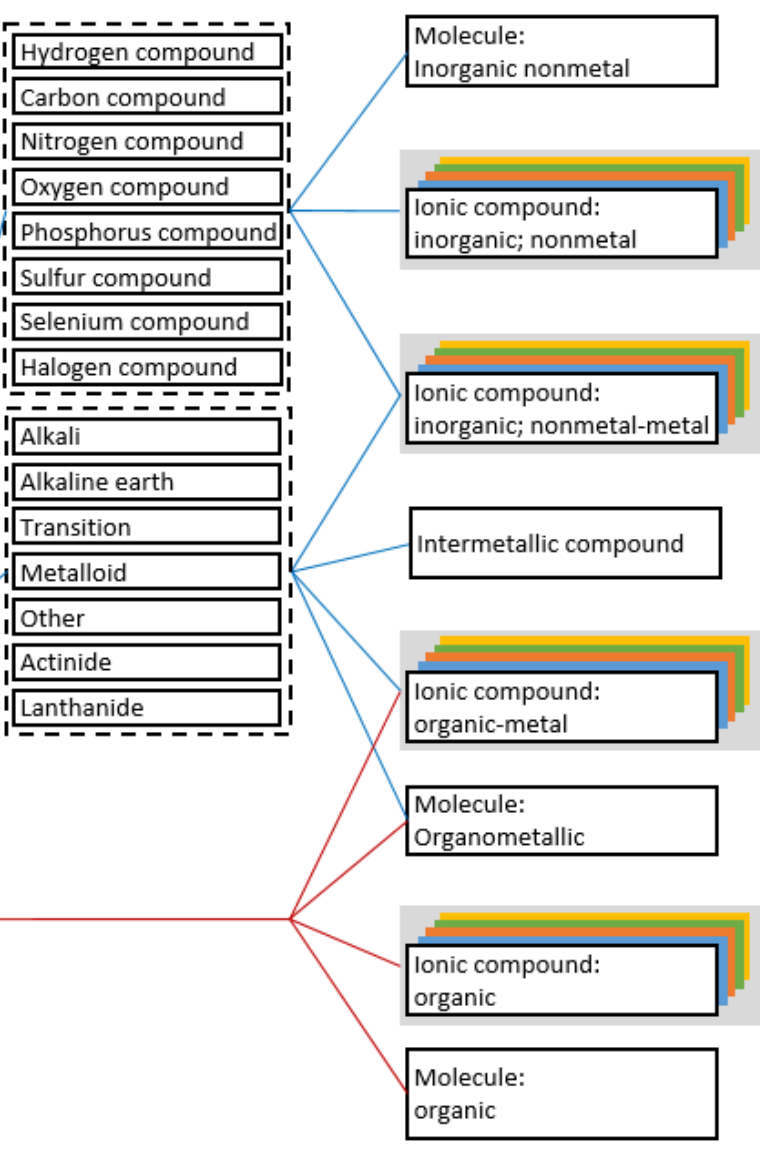

Example compound:

Carbon dioxide

Ammonium sulfate $\left(\mathrm{NH}_{4}\right)_{2} \mathrm{SO}_{4}$

Potassium cyanide $\mathrm{KCN}$

Nickel aluminide NiAl

Barium acetate $\left(\mathrm{Ba}\left(\mathrm{C}_{2} \mathrm{H}_{3} \mathrm{O}_{2}\right)_{2}\right)$

Butyltin trichloride $\mathrm{C}_{4} \mathrm{H}_{9} \mathrm{SnCl}_{3}$

Peg-5 cocomonium methosulfate

Heptachlor $\mathrm{C}_{10} \mathrm{H}_{5} \mathrm{Cl}_{7}$

Figure 1: Classification system for distinguishing chemical substances using different levels of refinement with focus on inorganic substances. 
The chosen life cycle impact assessment method ReCiPe V1.12 (Goedkoop et al., 2009) reveals that life cycle emissions of few particular inorganic substances (e.g. greenhouse gases) are characterized in terms of impacts associated with impact categories other than toxicityrelated impacts (Table 2), while the majority of inorganic substances belongs to toxicityrelated impact categories (i.e. human toxicity and ecotoxicity) but is neither included in toxicity characterization results nor in any other impact category. This is representative for how inorganic substances are handled across existing characterization methods (Hauschild and Huijbregts, 2015; Fantke et al., 2018a). In ReCiPe, 38 inorganic substances are characterized in different impact categories. Emissions of inorganic (and organic) greenhouse gases are characterized in terms of their climate change-related impact potential. Emissions of element's radioisotopes are characterized in terms of ionizing radiation. Fossil resource depletion is estimated based on elemental carbon, and mineral resource depletion based on using elemental metals. Marine and freshwater eutrophication are respectively associated with emissions of nitrogen and phosphorus containing compounds. Emissions of acidifying substances, such as ammonia, nitrogen oxide, and sulfur oxide, are characterized in terms of their potential to cause terrestrial acidification. Particulate matter related impacts included emission of primary particles and formation of secondary particles from precursors containing organic and/or inorganic components. Photochemical oxidant formation is associated with emissions of inorganic air pollutants as well as different non-methane volatile organic compounds. Finally, while a handful of inorganic substances (despite some metals and various organic substances) is included in the human toxicity and ecotoxicity related impact categories in ReCiPe, these substances are currently not adequately characterized.

Table 2: Inorganic substances characterized in the ReCiPe life cycle impact assessment method in terms of different impact categories.

\begin{tabular}{lcll}
\hline $\begin{array}{l}\text { Impact Category } \\
\text { Number of Chemical groups covered } \\
\text { inorganic } \\
\text { substances }\end{array}$ & Example substances \\
\hline Climate change & 2 & $\begin{array}{l}\text { Inorganic compounds } \\
\text { (nonmetal) } \\
\text { Elements (metal) }\end{array}$ & $\begin{array}{l}\text { Sulfur hexafluoride, carbon dioxide, } \\
\text { nitrous oxide } \\
\text { Actinium, americium } \\
\text { Carbon (coal) }\end{array}$ \\
$\begin{array}{l}\text { Fossil resources } \\
\text { depletion }\end{array}$ & 1 & Elements (nonmetal) & $\begin{array}{l}\text { Lead, gold, silver, nickel, zinc, } \\
\text { aluminum } \\
\text { Mineral resources } \\
\text { depletion }\end{array}$ \\
$\begin{array}{l}\text { Marine } \\
\text { eutrophication }\end{array}$ & 15 & Elements (metal) & $\begin{array}{l}\text { Nitrogen, nitrogen dioxide, ammonia, } \\
\text { nitrite, cyanide }\end{array}$ \\
\hline
\end{tabular}




\begin{tabular}{lcll}
\hline $\begin{array}{l}\text { Impact Category } \\
\text { Number of Chemical groups covered } \\
\text { inorganic } \\
\text { substances }\end{array}$ & Example substances \\
\hline $\begin{array}{l}\text { Freshwater } \\
\text { eutrophication }\end{array}$ & 3 & $\begin{array}{l}\text { Elements, inorganic } \\
\text { compounds, ions (nonmetal) }\end{array}$ & $\begin{array}{l}\text { Phosphorus, phosphate, phosphoric } \\
\text { acid }\end{array}$ \\
$\begin{array}{l}\text { Terrestrial } \\
\text { acidification }\end{array}$ & 4 & $\begin{array}{l}\text { Inorganic compounds } \\
\text { (nonmetal) }\end{array}$ & $\begin{array}{l}\text { Nitrogen dioxide, ammonia, sulfur } \\
\text { dioxide }\end{array}$ \\
$\begin{array}{l}\text { Particulate matter } \\
\text { formation }\end{array}$ & 4 & $\begin{array}{l}\text { Inorganic compounds } \\
\text { (nonmetal) }\end{array}$ & $\begin{array}{l}\text { Particulate matter, nitrogen dioxide, } \\
\text { ammonia, sulfur dioxide }\end{array}$ \\
$\begin{array}{l}\text { Photochemical } \\
\text { oxidant formation }\end{array}$ & 4 & $\begin{array}{l}\text { Inorganic compounds } \\
\text { (nonmetal) }\end{array}$ & $\begin{array}{l}\text { Nitrogen dioxide, sulfur dioxide, } \\
\text { carbon monoxide }\end{array}$ \\
$\begin{array}{l}\text { Human toxicity } \\
\text { (cancer and non- } \\
\text { cancer) }\end{array}$ & 39 & $\begin{array}{l}\text { Elements, inorganic } \\
\text { compounds*, ions (nonmetal* } \\
\text { metal and nonmetal*, metal) }\end{array}$ & $\begin{array}{l}\text { Ammonium carbonate, selenium, } \\
\text { carbon disulfide, aluminium } \\
\text { phosphate, sodium azide, strontium, } \\
\text { vanadium, copper, arsenic, zinc }\end{array}$ \\
$\begin{array}{l}\text { Ecotoxicity } \\
\text { (freshwater and } \\
\text { terrestrial } \\
\text { ecosystems) }\end{array}$ & 39 & $\begin{array}{l}\text { Elements, inorganic } \\
\text { compounds*, ions (nonmetal*, } \\
\text { metal and nonmetal*, metal) }\end{array}$ & $\begin{array}{l}\text { Ammonium carbonate, selenium, } \\
\text { carbon disulfide, aluminium } \\
\text { phosphate, sodium azide, strontium, } \\
\text { vanadium, copper, arsenic, zinc }\end{array}$ \\
\hline
\end{tabular}

*Inorganic substances other than metal ions are characterized following the approach that is only valid

352 for characterizing organic substances.

\subsection{Relevance of inorganic substances for human toxicity and ecotoxicity} characterization

Economic relevance: When analyzing the environmental performance of product life cycles, potential chemical substances emission flows have to be quantified in the inventory analysis phase. Ideally, emissions of all substances of economic relevance (i.e. involved in any production process along the product's life cycle) are included in the inventory and thus have to be characterized in terms of relevant environmental impacts. As one of the potential indicators to determine the economic relevance of inorganic compounds, the annual production volume within and import volume into the EEA for substances registered under the REACH Regulation have been systematically analyzed. Of the 14814 substances registered under REACH as of 15/01/2018, 986 have been identified as inorganic compound or element. Elements were split into two main groups, namely elemental metals $\left(\mathrm{E}_{\mathrm{m}}\right)$ and elemental nonmetals $\left(\mathrm{E}_{\mathrm{nm}}\right)$. Analogously, inorganic compounds were split into three main groups, $\mathrm{IC}_{\mathrm{nm}}, \mathrm{IC}_{\mathrm{mnm}}$, and $\mathrm{IC}_{\mathrm{m}}$ (sixth level of refinement in Figure 1, including both inorganic molecules and inorganic ionic compounds). An overview of the count of all inorganic substances identified under REACH is provided in Figure 2a, disaggregated according to annual production/import volumes. $\mathrm{IC}_{\mathrm{mnm}}$ constitutes the largest group among inorganic 
372 indicates a high economic relevance, 481 inorganic substances have been identified to be

373 economically relevant, of which 443 are inorganic compounds and 38 are elements. With a

374 production/import volume of $>100$ million tonnes per year, iron mainly used for production of

375 metal and metal products is the inorganic substance with the highest economic relevance,

376 followed by 14 inorganic substances with annual production/import volumes of $\geq 10$ million

377 tonnes each, including sodium hydroxide (mainly used for the manufacturing of sodium salts,

378 paper, and $\mathrm{pH}$ regulators in organic synthesis, mining, and textile production, and as detergent

379 in household products), nitric acid (mainly used for the production of fertilizers, but also in

380 washing and cleaning products, polishes and waxes, and air care products), and different

381 metals and metal oxides, such as iron ore, calcium oxide, and aluminum oxide (mainly used

382 for manufacturing of metal products).
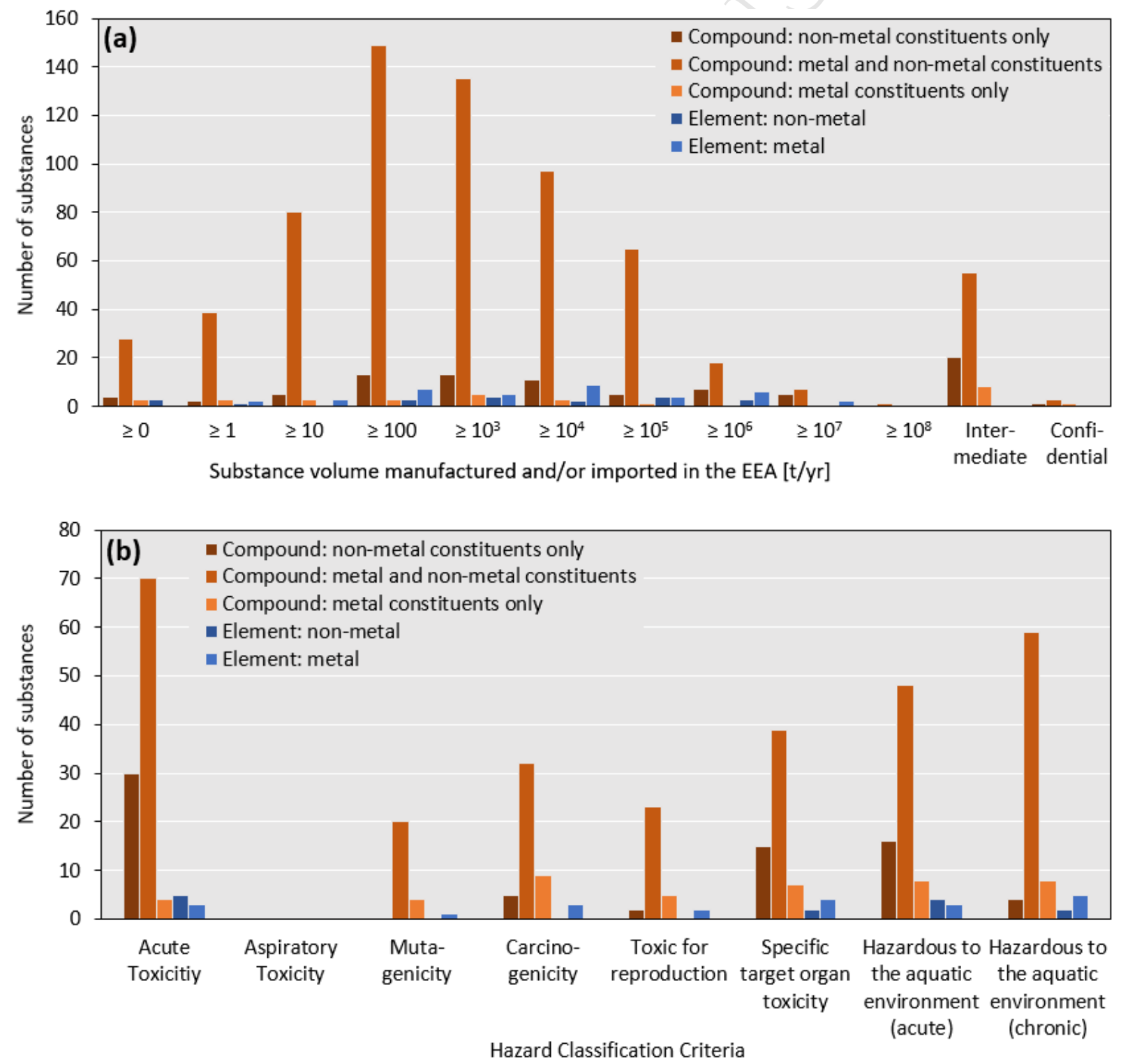
Figure 2: Categorization of inorganic substances registered under the REACH Regulation as of 15/01/2018 according to (a) substance volume manufactured and/or imported in the European Economic Area (EEA) per year with separate classes for substances used as "Intermediate" or claimed "Confidential", and according to (b) Hazard Classification Criteria based on the European CLP Regulation (EC) No 1272/2008.

Environmental relevance: Chemical emissions listed in any life cycle inventory can be characterized in terms of their contribution to different environmental impacts in an impact assessment, results of which can be used as an indication of the environmental relevance of the different emission flows. To identify environmentally relevant inorganic compounds contributing to toxicity-related impacts on humans and/or ecosystems, we analyzed the related substances registered under the REACH Regulation according to the hazard classification criteria of the European CLP Regulation (European Commission, 2008). More specifically, six toxicity and two ecotoxicity classification criteria were used, namely acute toxicity, aspiratory toxicity, carcinogenicity, germ cell mutagenicity, reproductive toxicity, specific target organ toxicity, and acute and chronic aquatic ecotoxicity (Figure 2b). Except for aspiratory toxicity, inorganic compounds and elements are found that are classified according to at least one of these hazard criteria. These substances were considered to be of environmental relevance. In all, 155 inorganic compounds and elements were identified to be hazardous according to the above-mentioned criteria. An example for a hazardous $\mathrm{IC}_{\mathrm{nm}}$ is chlorine dioxide used mainly in the manufacture of pulp, paper and paper products, which is classified as acute human toxic and acute hazardous to the aquatic environment. An example for hazardous $\mathrm{IC}_{\mathrm{mnm}}$ are barium sulfide and barium chloride, which are both classified as acute human toxic, whereas only the latter is also classified as acute hazardous to the aquatic environment. Both substances are used for the manufacturing of chemicals for different industrial applications.

Combined economic and environmental relevance: Most relevant in terms of human toxicity and ecotoxicity characterization are those inorganic substances that are both widely used (i.e. high production/import volume, see Figure 2a) as well as categorized as hazardous to humans or ecosystems (i.e. classified as hazardous according to CLP criteria, see Figure $2 b)$. Therefore, we combined the results of our analysis of the economic and environmental relevance for inorganic substances by intersecting the respective analysis criteria. In total, 82 inorganic compounds and 9 inorganic elements (9\% of all inorganic substances currently 
419 registered under $\mathrm{REACH}$ ) were found that are produced/imported more than 1000 tonnes per

420 year and that at the same time are classified as hazardous according to at least one of the

421 seven considered CLP hazard classification criteria. Results are shown in Figure 3, where we

422 focused on inorganic compounds. We found 19 compounds of the group of nonmetal

423 constituents having a high production/import volume (i.e. $\geq 1,000 \mathrm{t} / \mathrm{yr}$ ) and being classified as

424 hazardous according to at least one of the given CLP criteria. Within this compound group,

425 ammonium chloride, carbon disulfide, hydrogen fluoride, hydrogen chloride, hydrogen

426 peroxide, chlorine dioxide, and anhydrous ammonia are of special economic and

427 environmental relevance, because they are produced/imported in very high amounts $(\geq 10000$

$428 \mathrm{t} / \mathrm{yr}$ ), and each of these compounds is classified as being toxic to humans. Chlorine dioxide

429 and ammonia are additionally classified as hazardous to the aquatic environment.

430 Furthermore, we identified 60 relevant inorganic compounds of metal and nonmetal

431 constituents. Some of these compounds that are produced/imported in very high amounts

$432(>10,000 \mathrm{t} / \mathrm{yr})$ are classified as toxic to humans and hazardous to ecosystems, such as barium

433 sulfide, sodium chlorate, and nickel matte/nickel sulfide. Other substances listed in this

434 compound group are exclusively classified as human toxic, such as silicon tetrachloride,

435 calcium cyanamide, and sodium hydrogen sulfite, or hazardous to ecosystems, such as zinc

436 oxide or sodium hypochlorite. Inorganic substances identified as being both of high economic

437 relevance and toxic to humans and/or ecosystems are those of primary focus for developing

438 methods for characterizing their impacts in terms of potential human toxicity and ecotoxicity. 
(a) Inorganic compounds: non-metal constituents only $\left(\mathrm{IC}_{\mathrm{nm}}\right)$

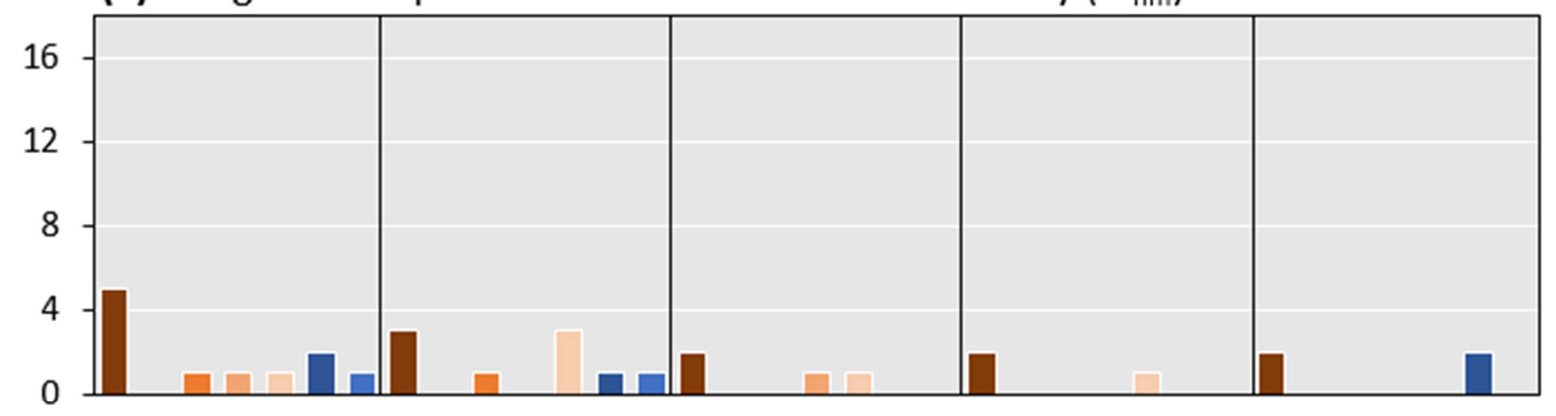

(b) Inorgainc compounds: metal and non-metal constituents $\left(\mathrm{IC}_{\mathrm{mnm}}\right)$

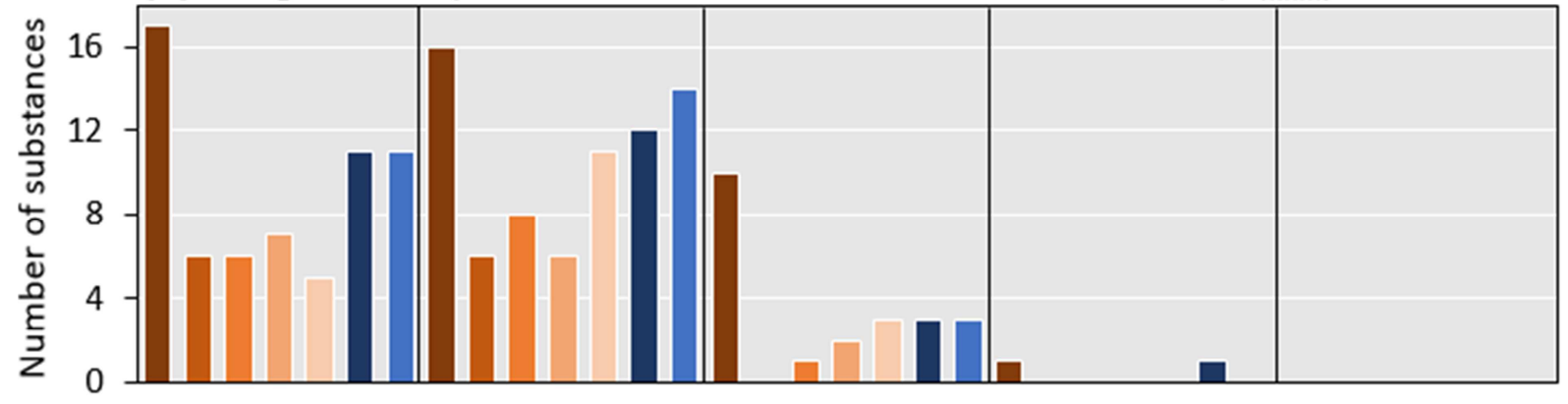

(c) Inorganic compounds: metal constituents only $\left(\mathrm{IC}_{\mathrm{m}}\right)$

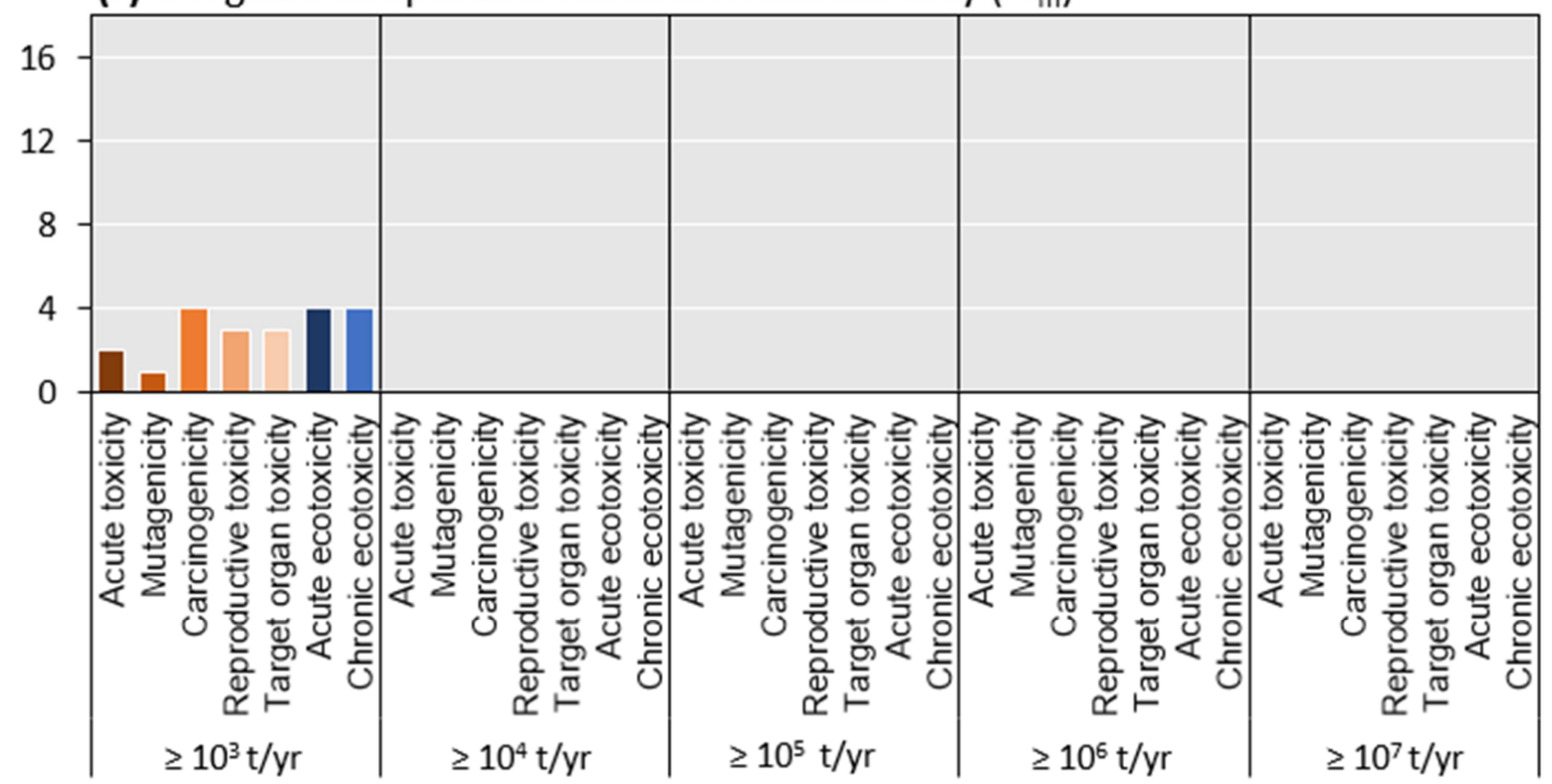

Hazard Classitication Criteria per annual import/production volume class

Figure 3: Inorganic compounds registered under REACH as of 15/01/2018 with high annual production/import volumes into the European Economic Area and classified according to one or more Hazard Classification Criteria of Regulation (EC) No 1272/2008.

In Table 3, we provide a detailed overview of all inorganic compounds and elements registered under the REACH Regulation that are considered a priority for toxicity and ecotoxicity characterization. We note that the suggested substances listed in Table 3 are limited to substances registered under the REACH Regulation as of January 2018. We 
449 furthermore acknowledge that some of the listed inorganic substances might not be of similar

450 economic relevance outside the European Union, while there might be additional inorganic

451 substances that are economically relevant elsewhere but not in the European Union. However,

452 the REACH registration process is not finished yet and several thousand of substances will

453 still have to be registered in consequence of the last registration milestone in 2018. 
Table 3: Inorganic compounds $(n=82)$ and elements $(n=9)$ registered under REACH as of 15/01/2018, which have been identified as being Area, and their classification according to the European CLP regulation.

\begin{tabular}{|c|c|c|c|c|c|c|c|c|c|c|c|c|c|c|}
\hline \multirow[b]{2}{*}{ Substance group } & \multirow[b]{2}{*}{ CAS } & \multirow[b]{2}{*}{ IUPAC name } & \multirow[b]{2}{*}{ Main group } & \multicolumn{3}{|c|}{ Substance used in } & \multirow[b]{2}{*}{$\begin{array}{l}\text { Tonnage band } \\
{[\mathrm{t} / \mathrm{yr}]}\end{array}$} & \multirow[b]{2}{*}{ AT } & \multirow[b]{2}{*}{ M } & \multirow[b]{2}{*}{ C } & \multirow[b]{2}{*}{$\mathrm{R}$} & \multirow[b]{2}{*}{ ST } & \multirow[b]{2}{*}{ AA } & \multirow[b]{2}{*}{$A C$} \\
\hline & & & & $\begin{array}{c}\text { Consumer/ } \\
\text { occupational } \\
\text { products }\end{array}$ & $\begin{array}{l}\text { Industrial } \\
\text { products }\end{array}$ & $\begin{array}{c}\text { Manufacture of } \\
\text { industrial } \\
\text { products }\end{array}$ & & & & & & & & \\
\hline \multirow{4}{*}{ Transition metal } & 7440-66-6 & Zinc & $E_{m}$ & $x$ & $x$ & $x$ & $\geq 10^{6}$ & & & & & & 1 & 1 \\
\hline & \begin{tabular}{|l|}
$7440-02-0$ \\
\end{tabular} & Nickel & $E_{m}$ & $x$ & $x$ & $x$ & $\geq 10^{5}$ & & & 2 & & RE 1 & & 3 \\
\hline & \begin{tabular}{|l|}
$7440-48-4$ \\
\end{tabular} & Cobalt & $E_{m}$ & $x$ & $x$ & $x$ & $\geq 10^{4}$ & & & & & & & 4 \\
\hline & 7440-43-9 & Cadmium & $E_{m}$ & $x$ & $x$ & $x$ & $\geq 10^{3}$ & 2 & 2 & $1 \mathrm{~B}$ & 2 & RE 1 & 1 & 1 \\
\hline \multirow{3}{*}{ Halogen } & $7782-50-5$ & Chlorine & $E_{n m}$ & $x$ & $x$ & $x$ & $\geq 10^{6}$ & 3 & & & & SE 3 & 1 & \\
\hline & 7726-95-6 & Bromine & $E_{n m}$ & & $x$ & $x$ & $\geq 10^{4}$ & 2 & & & & & 1 & \\
\hline & 7553-56-2 & lodine & $E_{n m}$ & $x$ & $x$ & $x$ & $\geq 10^{3}$ & 4 & & & & & 1 & \\
\hline \multirow[b]{2}{*}{ Other nonmetal } & 7782-49-2 & Selenium & $E_{n m}$ & & $x$ & $x$ & $\geq 10^{3}$ & 3 & & & & RE 2 & & 4 \\
\hline & $\begin{array}{l}7723-14-0 \\
12185-10-3\end{array}$ & Phosphorus & $E_{n m}$ & $x$ & $x$ & $x$ & $\geq 10^{3}$ & 2 & & & & & 1 & 3 \\
\hline Metal acid & 10043-35-3 & Boric acid & $I C_{\mathrm{mnm}}$ & $x$ & $x$ & $x$ & $\geq 10^{5}$ & & & & $1 \mathrm{~B}$ & & & \\
\hline \multirow{2}{*}{ Metal carbonate } & 513-77-9 & Barium carbonate & $I C_{m n m}$ & $x$ & $x$ & $x$ & $\geq 10^{5}$ & 4 & & & & & & \\
\hline & $513-79-1$ & Cobalt carbonate & $I C_{m n m}$ & $x$ & $x$ & $x$ & $\geq 10^{3}$ & & 2 & $1 \mathrm{~B}$ & $1 \mathrm{~B}$ & & 1 & 1 \\
\hline \begin{tabular}{|l|} 
Metal carbonate \\
hydroxide \\
\end{tabular} & 169314-88-9 & $\begin{array}{l}\text { Aluminium-magnesium-zinc- } \\
\text { carbonate-hydroxide }\end{array}$ & $\mathrm{IC}_{\mathrm{mnm}}$ & & $x$ & $x$ & $\geq 10^{4}$ & & & & & & & 4 \\
\hline \multirow{2}{*}{\begin{tabular}{|l} 
Metal cyanamide \\
$\begin{array}{l}\text { Metal dithionite/ } \\
\text { sulfite }\end{array}$ \\
\end{tabular}} & $156-62-7$ & Calcium cyanamide & $I C_{m n m}$ & $x$ & & $x$ & $\geq 10^{5}$ & 4 & & & & SE 3 & & \\
\hline & 7775-14-6 & Sodium dithionite & $\mathrm{I} \mathrm{C}_{\mathrm{mnm}}$ & $x$ & $x$ & $x$ & $\geq 10^{5}$ & 4 & & & & & & \\
\hline \multirow{11}{*}{ Metal halide } & 10026-04-7 & Silicon tetrachloride & $\mathrm{I} \mathrm{C}_{\mathrm{mnm}}$ & & $x$ & $x$ & $\geq 10^{5}$ & & & & & SE 3 & & \\
\hline & $10025-78-2$ & Trichlorosilane & $I C_{m n m}$ & & $x$ & $x$ & $\geq 10^{5}$ & 4 & & & & & & \\
\hline & \begin{tabular}{|l|}
$7718-54-9$ \\
\end{tabular} & Nickel dichloride & $I C_{m n m}$ & $x$ & $x$ & $x$ & $\geq 10^{4}$ & 3 & 2 & $1 \mathrm{~A}$ & $1 \mathrm{~B}$ & RE 1 & 1 & 1 \\
\hline & 13775-53-6 & Trisodium hexafluoroaluminate & $\mathrm{IC}_{\mathrm{mnm}}$ & $x$ & $x$ & $x$ & $\geq 10^{4}$ & 4 & & & & RE 1 & & 2 \\
\hline & 7646-85-7 & Zinc chloride & $I C_{m n m}$ & $x$ & $x$ & $x$ & $\geq 10^{4}$ & 4 & & & & & 1 & 1 \\
\hline & $10361-37-2$ & Barium chloride & $I C_{m n m}$ & $x$ & $x$ & $x$ & $\geq 10^{4}$ & 3 & & & & & & \\
\hline & \begin{tabular}{|l|}
$7646-79-9$ \\
\end{tabular} & Cobalt dichloride & $I C_{m n m}$ & $x$ & $x$ & $x$ & $\geq 10^{3}$ & 4 & 2 & $1 \mathrm{~B}$ & $1 \mathrm{~B}$ & & 1 & 1 \\
\hline & 7758-89-6 & Copper chloride & $I C_{m n m}$ & $x$ & $x$ & $x$ & $\geq 10^{3}$ & 4 & & & & & 1 & 1 \\
\hline & 7637-07-2 & Boron trifluoride & $I C_{m n m}$ & & $x$ & $x$ & $\geq 10^{3}$ & 2 & & & & & & \\
\hline & \begin{tabular}{|l|}
$7789-23-3$ \\
\end{tabular} & Potassium fluoride & $I C_{m n m}$ & $x$ & $x$ & $x$ & $\geq 10^{3}$ & 3 & & & & & & \\
\hline & 7681-49-4 & Sodium fluoride & $I C_{m n m}$ & $x$ & $x$ & $x$ & $\geq 10^{3}$ & 3 & & & & & & \\
\hline Metal halide & 16893-85-9 & Disodium hexafluorosilicate & $\mathrm{IC}_{\mathrm{mnm}}$ & & $x$ & $x$ & $\geq 10^{4}$ & 3 & & & & & & \\
\hline
\end{tabular}




\begin{tabular}{|c|c|c|c|c|c|c|c|c|c|c|c|c|c|c|}
\hline \multirow{3}{*}{ Substance group } & \multirow[b]{2}{*}{ CAS } & \multirow[b]{2}{*}{ IUPAC name } & \multirow[b]{2}{*}{ Main group } & \multicolumn{3}{|c|}{ Substance used in } & \multirow[b]{2}{*}{$\begin{array}{c}\text { Tonnage band } \\
{[\mathrm{t} / \mathrm{yr}]}\end{array}$} & \multirow[b]{2}{*}{ AT } & \multirow[b]{2}{*}{$\mathrm{M}$} & \multirow[b]{2}{*}{ C } & \multirow[b]{2}{*}{$R$} & \multirow[b]{2}{*}{ ST } & \multirow[b]{2}{*}{ AA } & \multirow[b]{2}{*}{$\mathrm{AC}$} \\
\hline & & & & $\begin{array}{c}\text { Consumer/ } \\
\text { occupational } \\
\text { products }\end{array}$ & $\begin{array}{l}\text { Industrial } \\
\text { products }\end{array}$ & \begin{tabular}{|c}
$\begin{array}{c}\text { Manufacture of } \\
\text { industrial } \\
\text { products }\end{array}$ \\
\end{tabular} & & & & & & & & \\
\hline & 16871-90-2 & Dipotassium hexafluorosilicate & $\mathrm{IC} \mathrm{C}_{\mathrm{mn}}$ & & $x$ & $x$ & $\geq 10^{3}$ & 3 & & & & & & \\
\hline \multirow{5}{*}{ Metal halogenite } & 7681-52-9 & Sodium hypochlorite & $I C_{m n m}$ & $x$ & $x$ & $x$ & $\geq 10^{6}$ & & & & & & 1 & \\
\hline & $7775-09-9$ & Sodium chlorate & $\mathrm{I} \mathrm{C}_{\mathrm{mnm}}$ & & $x$ & $x$ & $\geq 10^{5}$ & 4 & & & & & & 2 \\
\hline & 3811-04-9 & Potassium chlorate & $\mathrm{I} \mathrm{C}_{\mathrm{mnm}}$ & $x$ & $x$ & $x$ & $\geq 10^{3}$ & 4 & & & & & & 2 \\
\hline & \begin{tabular}{|l|}
$7778-54-3$ \\
\end{tabular} & Calcium hypochlorite & $\mathrm{IC} \mathrm{C}_{\mathrm{mm}}$ & & & $\mathrm{C}$ & $\geq 10^{3}$ & 4 & & & & & 1 & \\
\hline & $7601-89-0$ & Sodium perchlorate & $\mathrm{IC} \mathrm{m}_{\mathrm{mm}}$ & $x$ & $x$ & $x$ & $\geq 10^{3}$ & 4 & & & & & & \\
\hline $\begin{array}{l}\text { Metal hydrogen } \\
\text { sulfite }\end{array}$ & 7631-90-5 & Sodium hydrogensulfite & $\mathrm{IC}_{\mathrm{mnm}}$ & $x$ & $x$ & $x$ & $\geq 10^{5}$ & 4 & & & & & & \\
\hline \multirow{2}{*}{ Metal hydroxide } & $1310-58-3$ & Potassium hydroxide & $\mathrm{I} \mathrm{C}_{\mathrm{mnm}}$ & $x$ & $\mathrm{x}$ & 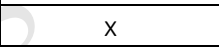 & $\geq 10^{5}$ & 4 & & & & & & \\
\hline & $12054-48-7$ & Nickel dihydroxide & $\mathrm{I} \mathrm{C}_{\mathrm{mnm}}$ & & $x$ & $x$ & $\geq 10^{3}$ & 4 & 2 & $1 \mathrm{~A}$ & $1 \mathrm{~B}$ & RE 1 & 1 & 1 \\
\hline $\begin{array}{l}\text { Metal hydroxy } \\
\text { carbonate }\end{array}$ & $12607-70-4$ & $\begin{array}{l}\text { [carbonato(2- } \\
\text { )]tetrahydroxytrinickel }\end{array}$ & $\mathrm{I} \mathrm{C}_{\mathrm{mnm}}$ & $x$ & $x$ & $x$ & $\geq 10^{3}$ & 4 & 2 & $1 \mathrm{~A}$ & $1 \mathrm{~B}$ & RE 1 & 1 & 1 \\
\hline Metal nitrate & $13138-45-9$ & Nickel dinitrate & $\mathrm{I} \mathrm{C}_{\mathrm{mnm}}$ & $x$ & $x$ & $x$ & $\geq 10^{3}$ & 4 & 2 & $1 \mathrm{~A}$ & $1 \mathrm{~B}$ & RE 1 & 1 & 1 \\
\hline Metal nitrite & $7632-00-0$ & Sodium nitrite & $I C_{m n m}$ & $x$ & $x$ & $x$ & $\geq 10^{4}$ & 3 & & & & & 1 & \\
\hline \multirow{16}{*}{ Metal oxide } & $1314-13-2$ & Zinc oxide & $\mathrm{I} \mathrm{C}_{\mathrm{mnm}}$ & $x$ & $x$ & $x$ & $\geq 10^{5}$ & & & & & & 1 & 1 \\
\hline & $1333-82-0$ & Chromium trioxide & $\mathrm{I} \mathrm{C}_{\mathrm{mnm}}$ & $x$ & $x$ & $x$ & $\geq 10^{4}$ & 2 & $1 \mathrm{~B}$ & $1 \mathrm{~A}$ & 2 & RE 1 & 1 & 1 \\
\hline & 1314-62-1 & Divanadium pentaoxide & $I C_{m n m}$ & $x$ & $x$ & $x$ & $\geq 10^{4}$ & 4 & 2 & & 2 & RE 1 & & 2 \\
\hline & 1313-99-1 & Nickel monoxide & $I C_{m n m}$ & 4 & $x$ & $x$ & $\geq 10^{4}$ & & & $1 \mathrm{~A}$ & & RE 1 & & 4 \\
\hline & $1313-27-5$ & Molybdenum trioxide & $I C_{m n m}$ & $\mathrm{~N} \times$ & $x$ & $x$ & $\geq 10^{4}$ & & & 2 & & SE 3 & & \\
\hline & 1313-13-9 & Manganese dioxide & $\mathrm{IC}_{\mathrm{mnm}}$ & $\mathrm{x}$ & $x$ & $x$ & $\geq 10^{4}$ & 4 & & & & & & \\
\hline & 1309-64-4 & Diantimony trioxide & $I C_{m n m}$ & $x$ & $x$ & $x$ & $\geq 10^{4}$ & & & 2 & & & & \\
\hline & 1306-19-0 & Cadmium oxide & $I C_{\mathrm{mnm}}$ & $y$ & $x$ & $x$ & $\geq 10^{3}$ & 2 & 2 & $1 \mathrm{~B}$ & 2 & RE 1 & 1 & 1 \\
\hline & 1307-96-6 & Cobalt oxide & $I C_{\mathrm{mnm}}$ & $x$ & $x$ & $x$ & $\geq 10^{3}$ & 4 & & & & & 1 & 1 \\
\hline & 1317-39-1 & Dicopper oxide & $\mathrm{IC}_{\mathrm{mnm}}$ & $x$ & $x$ & $x$ & $\geq 10^{3}$ & 4 & & & & & 1 & 1 \\
\hline & $1303-86-2$ & Diboron trioxide & $I C_{m n m}$ & $x$ & $x$ & $x$ & $\geq 10^{3}$ & & & & $1 \mathrm{~B}$ & & & \\
\hline & $\begin{array}{l}1303-96-4 \\
1330-43-4 \\
12179-04-3\end{array}$ & $\begin{array}{l}\text { Disodium tetraborate, } \\
\text { anhydrous }\end{array}$ & $\mathrm{IC}_{\mathrm{mnm}}$ & $x$ & $x$ & $x$ & $\geq 10^{5}$ & & & & $1 \mathrm{~B}$ & & & \\
\hline & \begin{tabular}{|l|}
$11138-47-9$ \\
$12040-72-1$ \\
$37244-98-7$ \\
\end{tabular} & Perboric acid, sodium salt & $I C_{m n m}$ & $x$ & & & $\geq 10^{4}$ & 3 & & & $1 \mathrm{~B}$ & SE 3 & & \\
\hline & $\begin{array}{l}7789-12-0 \\
10588-01-9\end{array}$ & Sodium dichromate & $I C_{m n m}$ & $x$ & $x$ & $x$ & $\geq 10^{3}$ & 2 & $1 \mathrm{~B}$ & $1 \mathrm{~B}$ & $1 \mathrm{~B}$ & RE 1 & 1 & 1 \\
\hline & $1344-37-2$ & Lead sulfochromate yellow & $\mathrm{I} \mathrm{C}_{\mathrm{mnm}}$ & $x$ & $x$ & $x$ & $\geq 10^{3}$ & & & $1 \mathrm{~B}$ & $1 \mathrm{~A}$ & RE 2 & 1 & 1 \\
\hline & $12656-85-8$ & $\begin{array}{l}\text { Lead chromate molybdate } \\
\text { sulfate red }\end{array}$ & $\mathrm{IC}_{\mathrm{mn}}$ & $x$ & $x$ & $x$ & $\geq 10^{3}$ & & & $1 B$ & $1 \mathrm{~A}$ & RE 2 & 1 & 1 \\
\hline
\end{tabular}




\begin{tabular}{|c|c|c|c|c|c|c|c|c|c|c|c|c|c|c|}
\hline \multirow{5}{*}{ Substance group } & \multirow[b]{2}{*}{ CAS } & \multirow[b]{2}{*}{ IUPAC name } & \multirow[b]{2}{*}{ Main group } & \multicolumn{3}{|c|}{ Substance used in } & \multirow[b]{2}{*}{$\begin{array}{l}\text { Tonnage band } \\
{[\mathrm{t} / \mathrm{yr}]}\end{array}$} & \multirow[b]{2}{*}{ AT } & \multirow[b]{2}{*}{ M } & \multirow[b]{2}{*}{$C$} & \multirow[b]{2}{*}{$\mathrm{R}$} & \multirow[b]{2}{*}{ ST } & \multirow[b]{2}{*}{ AA } & \multirow[b]{2}{*}{$A C$} \\
\hline & & & & $\begin{array}{c}\text { Consumer/ } \\
\text { occupational } \\
\text { products } \\
\end{array}$ & $\begin{array}{l}\text { Industrial } \\
\text { products }\end{array}$ & $\begin{array}{c}\text { Manufacture of } \\
\text { industrial } \\
\text { products }\end{array}$ & & & & & & & & \\
\hline & 7789-06-2 & Strontium chromate & $\mathrm{I} \mathrm{C}_{\mathrm{mnm}}$ & & $x$ & s & $\geq 10^{3}$ & 4 & & $1 \mathrm{~B}$ & & & 1 & 1 \\
\hline & 7722-64-7 & Potassium permanganate & $I C_{m n m}$ & $x$ & $x$ & $\mathrm{x}$ & $\geq 10^{3}$ & 4 & & & & & 1 & 1 \\
\hline & $6834-92-0$ & Disodium metasilicate & $I C_{\mathrm{mnm}}$ & $x$ & $x$ & $x$ & $\geq 10^{4}$ & & & & & SE 3 & & \\
\hline Metal phosphate & 7779-90-0 & Trizinc bis(orthophosphate) & $I C_{m n m}$ & $x$ & $x$ & $x$ & $\geq 10^{4}$ & & & & & & 1 & 1 \\
\hline \multirow{7}{*}{ Metal sulfate } & 7720-78-7 & Iron sulfate & $I C_{\mathrm{mnm}}$ & $x$ & $x$ & $x$ & $\geq 10^{6}$ & 4 & & & & & & \\
\hline & 7786-81-4 & Nickel sulfate & $I C_{m n m}$ & $x$ & $x$ & $x$ & $\geq 10^{4}$ & 4 & 2 & $1 \mathrm{~A}$ & $1 \mathrm{~B}$ & RE 1 & 1 & 1 \\
\hline & 10124-43-3 & Cobalt sulfate & $I C_{m n m}$ & $x$ & $x$ & $x$ & $\geq 10^{4}$ & 4 & 2 & $1 \mathrm{~B}$ & $1 \mathrm{~B}$ & & 1 & 1 \\
\hline & \begin{tabular}{|l|}
$7758-98-7$ \\
$7758-99-8$
\end{tabular} & Copper sulfate & $\mathrm{IC}_{\mathrm{mnm}}$ & $x$ & $x$ & ) & $\geq 10^{4}$ & 4 & & & & & 1 & 1 \\
\hline & \begin{tabular}{|l|}
$7446-19-7$ \\
$7733-02-0$ \\
\end{tabular} & Zinc sulfate & $\mathrm{I} \mathrm{C}_{\mathrm{mnm}}$ & $x$ & $x$ & $x$ & $\geq 10^{4}$ & 4 & & & & & 1 & 1 \\
\hline & 7785-87-7 & Manganese sulfate & $I C_{m n m}$ & $x$ & $x$ & $x$ & $\geq 10^{4}$ & & & & & RE 2 & & 2 \\
\hline & $7727-21-1$ & Dipotassium peroxodisulfate & $I C_{m n m}$ & $x$ & $x$ & $x$ & $\geq 10^{3}$ & 4 & & & & SE 3 & & \\
\hline \multirow{6}{*}{ Metal sulfide } & 69012-50-6 & Matte, nickel & $I C_{m n m}$ & & 3 & $x$ & $\geq 10^{5}$ & & & $1 \mathrm{~A}$ & & RE 1 & 1 & 1 \\
\hline & $21109-95-5$ & Barium sulfide & $I C_{m n m}$ & $x$ & . & $x$ & $\geq 10^{5}$ & 4 & & & & & 1 & \\
\hline & 16812-54-7 & Nickel sulfide & $I C_{m n m}$ & 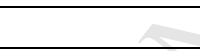 & $x$ & $x$ & $\geq 10^{4}$ & & 2 & $1 \mathrm{~A}$ & & RE 1 & 1 & 1 \\
\hline & $1313-82-2$ & Disodium sulphide & $I C_{\mathrm{mnm}}$ & $x$ & $x$ & $x$ & $\geq 10^{4}$ & 3 & & & & & 1 & \\
\hline & 1344-08-7 & Sodium sulfide & $I C_{m n m}$ & 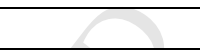 & $x$ & $x$ & $\geq 10^{4}$ & 3 & & & & & 1 & \\
\hline & 7681-57-4 & Disodium disulfite & $I C_{m n m}$ & $x$ & $x$ & $x$ & $\geq 10^{5}$ & 4 & & & & & & \\
\hline $\begin{array}{l}\text { Ammonium } \\
\text { halide }\end{array}$ & $12125-02-9$ & Ammonium chloride & $\mathrm{IC}_{\mathrm{nm}}$ & x & $\mathrm{x}$ & $x$ & $\geq 10^{5}$ & 4 & & & & & & \\
\hline $\begin{array}{l}\text { Ammonium } \\
\text { hydrogen halide }\end{array}$ & $1341-49-7$ & Ammonium hydrogendifluoride & $\mathrm{IC}_{\mathrm{nm}}$ & $x$ & $x$ & & $\geq 10^{3}$ & 3 & & & & & & \\
\hline $\begin{array}{l}\text { Ammoniumsulfat } \\
\text { e }\end{array}$ & $7727-54-0$ & Diammonium peroxodisulfate & $I C_{n m}$ & $\mathrm{x}$ & $x$ & $x$ & $\geq 10^{4}$ & 4 & & & & SE 3 & & \\
\hline Carbon sulfide & $75-15-0$ & Carbon disulphide & $I C_{n m}$ & $x$ & $x$ & $x$ & $\geq 10^{5}$ & & & & 2 & RE 1 & & \\
\hline Carboxide & $630-08-0$ & Carbon monoxide & $I C_{n m}$ & $x$ & $x$ & $x$ & $\geq 10^{3}$ & 3 & & & $1 \mathrm{~A}$ & RE 1 & & \\
\hline Halogen oxide & 10049-04-4 & Chlorine dioxide & $I C_{n m}$ & & $x$ & $x$ & $\geq 10^{7}$ & 2 & & & & & 1 & \\
\hline $\begin{array}{l}\text { Hydrogen } \\
\text { cyanamide }\end{array}$ & $420-04-2$ & Cyanamide & $I C_{n m}$ & & $x$ & $x$ & $\geq 10^{3}$ & 3 & & & & & & \\
\hline \multirow{3}{*}{ Hydrogen halide } & 7647-01-0 & Hydrogen chloride & $I C_{n m}$ & $x$ & $x$ & $x$ & $\geq 10^{6}$ & 3 & & & & SE 3 & & \\
\hline & 7664-39-3 & Hydrogen fluoride & $\mathrm{IC}_{\mathrm{nm}}$ & $x$ & $x$ & $x$ & $\geq 10^{5}$ & 1 & & & & & & \\
\hline & $10035-10-6$ & Hydrogen bromide & $I C_{n m}$ & & $x$ & $x$ & $\geq 10^{4}$ & & & & & SE 3 & & \\
\hline $\begin{array}{l}\text { Hydroxyl } \\
\text { ammonium } \\
\text { sulfate }\end{array}$ & 10039-54-0 & Bis(hydroxylammonium) sulfate & $\mathrm{IC}_{\mathrm{nm}}$ & & $x$ & $x$ & $\geq 10^{4}$ & 4 & & 2 & & RE 2 & 1 & \\
\hline Peroxide & $7722-84-1$ & Hydrogen peroxide & $I C_{n m}$ & $x$ & $x$ & $x$ & $\geq 10^{6}$ & 4 & & & & & & \\
\hline
\end{tabular}




\begin{tabular}{|c|c|c|c|c|c|c|c|c|c|c|c|c|c|c|}
\hline \multirow[b]{2}{*}{ Substance group } & \multirow[b]{2}{*}{ CAS } & \multirow[b]{2}{*}{ IUPAC name } & \multirow[b]{2}{*}{ Main group } & \multicolumn{3}{|c|}{ Substance used in } & \multirow[b]{2}{*}{$\begin{array}{c}\text { Tonnage band } \\
\text { [t/yr] }\end{array}$} & \multirow[b]{2}{*}{ AT } & \multirow[b]{2}{*}{ M } & \multirow[b]{2}{*}{ C } & \multirow[b]{2}{*}{$\mathrm{R}$} & \multirow[b]{2}{*}{ ST } & \multirow[b]{2}{*}{ AA } & \multirow[b]{2}{*}{$A C$} \\
\hline & & & & $\begin{array}{l}\text { Consumer/ } \\
\text { occupational } \\
\text { products }\end{array}$ & $\begin{array}{l}\text { Industrial } \\
\text { products }\end{array}$ & $\begin{array}{l}\text { Manufacture of } \\
\text { industrial } \\
\text { products }\end{array}$ & & & & & & & & \\
\hline Phosphorus acid & $13598-36-2$ & Phosphonic acid & $I C_{n m}$ & $x$ & $x$ & < & $\geq 10^{3}$ & 4 & & & & & & \\
\hline Sulfur dioxide & 7446-09-5 & Sulfur dioxide & $I C_{n m}$ & $x$ & $x$ & $x$ & $\geq 10^{5}$ & 3 & & & & & & \\
\hline Sulfur halide & 10025-67-9 & Disulfur dichloride & $I C_{n m}$ & & $x$ & $x$ & $\geq 10^{3}$ & 3 & & & & & 1 & \\
\hline Thionyl halide & 7719-09-7 & Sulfurous dichloride & $I C_{n m}$ & & & $x$ & $\geq 10^{4}$ & 4 & & & & & & \\
\hline \multirow{3}{*}{ Other } & 7664-41-7 & Ammonia, anhydrous & $I_{\mathrm{nm}}$ & $x$ & $x$ & $x$ & $\geq 10^{7}$ & 3 & & & & & 1 & \\
\hline & 5329-14-6 & Sulfamic acid & $I_{\mathrm{nm}}$ & $x$ & $x$ & $x$ & $\geq 10^{4}$ & & & & & & & 3 \\
\hline & \begin{tabular}{|l|}
$302-01-2$ \\
$7803-57-8$
\end{tabular} & Hydrazine & $I C_{n m}$ & $x$ & $x$ & $x$ & $\geq 10^{3}$ & 3 & & $1 \mathrm{~B}$ & & & 1 & 1 \\
\hline
\end{tabular}

$457{ }^{1}$ Production: Annual production and/or import volume for the European Economic Area in tonnes.

458 2 AT: acute toxicity; M: germ cell mutagenicity; C: carcinogenicity; R: reproductive toxicity; ST: specific target organ toxicity - within this 459 category, RE: repeated exposure; SE: single exposure.

$460{ }^{3}$ AA: acute ecotoxicity to aquatic organisms; AC: chronic ecotoxicity to aquatic organisms. 
In our overview of inorganic high-priority substances in Table 3, some of the main occurring substance groups are metal and nonmetal sulfates, halides, phosphates, and oxides.

463

464 This overview underlines that ionic compounds for the same metal can have different toxic effects (i.e. different hazard classifications), depending on the corresponding anion (e.g. barium sulfide, barium chloride, and barium carbonate).

\subsection{Challenges and future research needs for characterizing inorganic substances}

Inorganic substances identified in Table 3 are those, which are considered to be both economically and environmentally relevant. Hence, those are the inorganic substances identified to be of highest priority for developing human toxicity and ecotoxicity characterization factors for application in comparative and quantitative chemicals management frameworks including product life cycle assessment, chemical substitution and alternatives assessment, and high-throughput risk screening.

There are, however, several challenges associated with characterizing most of the identified inorganic substances. These challenges are primarily related to describing processes and characteristics important for understanding the environmental fate, exposure of humans and ecosystems, and potential toxicity-related effects associated with these substances. Future modeling approaches need to be developed that focus on addressing these challenges for successfully incorporating inorganic substances in toxicity characterization. Some of the main challenges are briefly described in the following in order to focus related future research efforts.

Environmental fate: The environmental fate (i.e. distribution and transformation between and within the difference environmental compartments, such as air, soil, water, and biota) of inorganic substances is governed by a complex, substance-specific reaction chemistry defined by several reaction products in different compartments as well as varying reaction kinetics that have to be taken into account. To provide concrete input for considering this aspect when developing or adapting toxicity characterization models for inorganic substances, we give an illustrative example of the (relatively simple) reaction kinetics for hydrogen cyanide (HCN) emitted to water is illustrated in Figure 4. Fate models that consider inorganic substances should include the formation of all relevant reaction products of an emitted substance in all compartments by modelling all involved processes including, for example, diffusion, oxidation, complexation, precipitation, and various degradation and transformation processes.

Exposure: For modeling the exposure of ecological organisms to inorganic compounds emitted to the environment, bioavailability is a key aspect that needs to be considered. The 
mass of an inorganic compound emitted or transferred into a specific compartment will in many cases not equal the mass that is bioavailable for ecological receptors, since bioavailability is dependent on, for example, compartment characteristics, such as $\mathrm{pH}$ and media temperature. Additionally, many inorganic substances interact with soil components or other substances found in soil. For example, halogen compounds do not act conservatively in soil or water, but are reactively involved in the organic matter cycling and are hence related to iron and manganese cycling by forming complexes (Ozutsumi et al., 1994). While emissions usually occur at different locations and times along product life cycles, in certain situations co-exposure of multiple substances might still be relevant, such as for consumer exposure, where consumers are exposed simultaneously to different chemical product constituents (Fantke et al., 2018b). In such situations, it would be relevant to consider possible interactions across chemicals.

Toxicity-related effects: Estimating toxicological and ecotoxicological effects for inorganic compounds is again a function of the complex reaction chemistry of these substances. Hence, effect data for all relevant and prevailing reaction products are required in effect characterization and need to be combined with the respective fractions that each reaction product occurs in the different environmental compartments or phases.

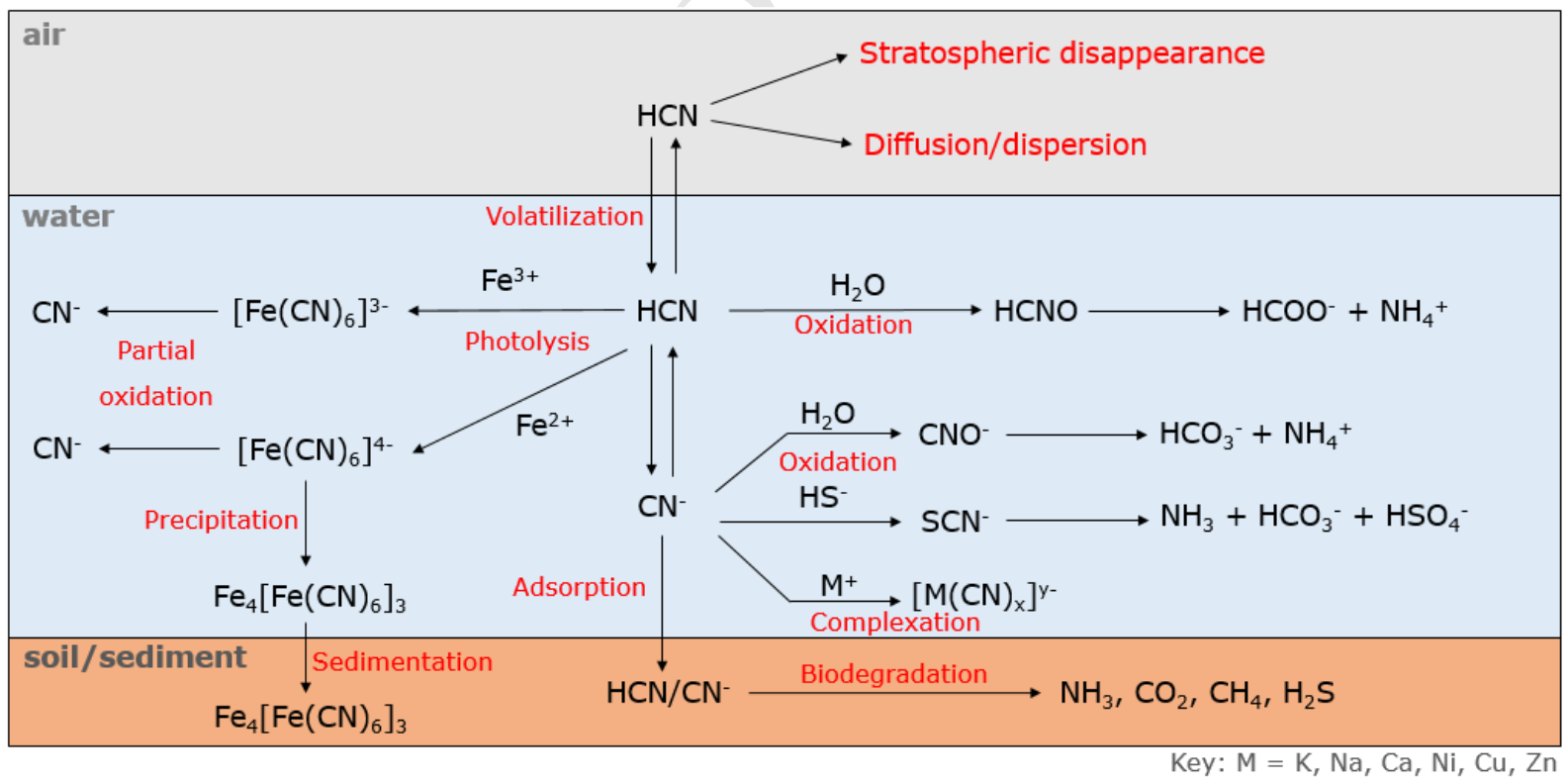

514 Figure 4: Reaction kinetics and related reaction products of hydrogen cyanide (HCN) emitted 515 into water (adapted from Mudder et al., 2001).

Limitations for this study result in the fact that the data analyzed are restricted to the EEA and thus manufacturing and production processes in Europe. Our results do not represent 
519 industries causing emissions of high volume and high toxicity substances, such as cyanide

520 compounds that have very high acute toxicity and are widely used e.g. in metal extraction

521 processes in several African countries. Yet, our results constitute a starting point for

522 highlighting relevant inorganic substances that occur in various processes in Europe and

523 elsewhere.

524

\section{Conclusions}

Currently, inorganic substances other than selected metal ions are largely missing in existing toxicity characterization methods, leaving an important gap unaddressed in assessments of environmental performance of products and services, chemical substitution, and substance prioritization. This renders the development of reliable chemicals management strategies difficult and could lead to decisions where certain environmental impacts are underestimated whenever potentially harmful but uncharacterized substances are involved. With the present study, we provide a starting point for characterizing around 90 inorganic high-priority substances based on identifying those substances that are both of high economic as well as of high environmental relevance. Mainly due to a complex reaction chemistry and data limitations for effect quantification, current methods cannot be applied without modification regarding fate, exposure, and toxicity effects of inorganic substances. Future research is required that targets the consideration of such complex reaction chemistries and that overcomes current data limitations to successfully consider inorganic substances in human toxicity and ecotoxicity characterization, ultimately leading to a more comprehensive decision support in line with the global sustainability agenda set for chemicals management.

\section{Acknowledgements}

We thank P. Karamertzanis and J. Provoost from the European Chemicals Agency for their kind support in extracting and providing selected REACH data.

\section{References}

Chitra, S., Sasidhar, P., Lal, K.B., Ahmed, J., 1999. The effect of common alkali and alkaline earth metal cations to the sorption of stronitium and cesium onto soil. J. Ind. Pollut. Contr. 15, 65-72. 
Egorova, K.S., Ananikov, V.P., 2017. Toxicity of metal compounds: Knowledge and myths. Organometallics 36, 4071-4090. doi:10.1021/acs.organomet.7b00605.

European Commission, 2006. Regulation (EC) No 1907/2006 of the European Parliament and of the Council of 18 December 2006 concerning the Registration, Evaluation, Authorisation and Restriction of Chemicals (REACH). Brussels, p. 849.

European Commission, 2008. Regulation (EC) No 1272/2008 of the European Parliament and of the Council of 16 December 2008 on classification, labelling and packaging of substances and mixtures, amending and repealing Directives 67/548/EEC and 1999/45/EC, and amending Regulation (EC) No 1907/2006. Brussels, p. 1355.

Fantke, P., Arnot, J.A., Doucette, W.J., 2016a. Improving plant bioaccumulation science through consistent reporting of experimental data. J. Environ. Manage. 181, 374-384. doi:10.1016/j.jenvman.2016.06.065.

Fantke, P., Aurisano, N., Backhaus, T., Bulle, C., Chapman, P.M., Cooper, C.A., De Zwart, D., Dwyer, R., Ernstoff, A., Golsteijn, L., Henderson, A., Holmquist, H., Jolliet, O., Kirchhübel, N., Nordheim, E., Otte, N., Owsianiak, M., Peijnenburg, W., Posthuma, L., Roos, S., Saouter, E., Schowanek, D., van Straalen, N., Vijver, M., Hauschild, M., 2018a. Toward harmonizing ecotoxicity characterization in life cycle impact assessment. Environ. Toxicol. Chem. 37, 2955-2971. doi:10.1002/etc.4261.

Fantke, P., Aylward, L., Bare, J., Chiu, W.A., Dodson, R., Dwyer, R., Ernstoff, A., Howard, B., Jantunen, M., Jolliet, O., Judson, R., Kirchhübel, N., Li, D., Miller, A., Paoli, G., Price, P., Rhomberg, L., Shen, B., Shin, H.-M., Teeguarden, J., Vallero, D., Wambaugh, J., Wetmore, B.A., Zaleski, R., McKone, T.E., 2018b. Advancements in life cycle human exposure and toxicity characterization. Environ. Health Perspect. 126, 125001. doi:10.1289/EHP3871.

Fantke, P., Ernstoff, A.S., Huang, L., Csiszar, S.A., Jolliet, O., 2016b. Coupled near-field and far-field exposure assessment framework for chemicals in consumer products. Environ. Int. 94, 508-518. doi:10.1016/j.envint.2016.06.010.

Fantke, P., Illner, N., 2019. Goods that are good enough: Introducing an absolute sustainability perspective for managing chemicals in consumer products. Curr. Opin. Green Sustain. Chem. 15, 91-97. doi:10.1016/j.cogsc.2018.12.001.

Fantke, P., Weber, R., Scheringer, M., 2015. From incremental to fundamental substitution in chemical alternatives assessment. Sustain. Chem. Pharm. 1, 1-8.

doi:10.1016/j.scp.2015.08.001.

Goedkoop, M., Heijungs, R., Huijbregts, M., De Schryver, A., Struijs, J., van Zelm, R., 2009. ReCiPe 2008: A life cycle impact assessment method which comprises harmonised category indicators at the midpoint and the endpoint level; First edition Report I: Characterisation, p. 132.

Greggs, B., Burns, T., Egeghy, P., Embry, M., Fantke, P., Gaborek, B., Heine, L., Jolliet, O., Lee, C., Muir, D., Plotzke, K., Rinkevich, J., Sunger, N., Tanir, J., Whittaker, M., 2018. Qualitative approach to comparative exposure in alternatives assessment. Integr. Environ. Assess. Manage. doi:10.1002/ieam.4070. 
Grimm, F.A., Iwata, Y., Sirenko, O., Chappell, G.A., Wright, F.A., Reif, D.M., Braisted, J., Gerhold, D.L., Yeakley, J.M., Shepard, P., Seligmann, B., Roy, T., Boogaard, P.J.,

Ketelslegers, H.B., Rohde, A.M., Rusyn, I., 2016. A chemical-biological similarity-based grouping of complex substances as a prototype approach for evaluating chemical alternatives. Green Chem. 18, 4407-4419. doi:10.1039/C6GC01147K.

Hauschild, M., Huijbregts, M.A.J., 2015. Life Cycle Impact Assessment. Springer Press, Dordrecht, The Netherlands.

Holleman, A.F., Wiberg, N., Wiberg, E., 2007. Lehrbuch der Anorganischen Chemie, 102nd Ed. Walter de Gruyter, Berlin, New York.

Iacovidou, E., Velis, C.A., Purnell, P., Zwirner, O., Brown, A., Hahladakis, J., MillwardHopkins, J., Williams, P.T., 2017. Metrics for optimising the multi-dimensional value of resources recovered from waste in a circular economy: A critical review. J. Cleaner Prod. 166, 910-938. doi:10.1016/j.jclepro.2017.07.100.

Landner, L., Reuther, R., 2004. Metals in Society and in the Environment: A Critical Review of Current Knowledge on Fluxes, Speciation, Bioavailability and Risk for Adverse Effects of Copper, Chromium, Nickel and Zinc. Kluwer Academic Publishers, Dordrecht.

Mudder, T.I., Botz, M.M., Smith, A., 2001. Chemistry and Treatment of Cyanidation Wastes, 2nd Ed. Mining Journal Books Ltd., London.

Müller, N., de Zwart, D., Hauschild, M., Kijko, G., Fantke, P., 2017. Exploring REACH as potential data source for characterizing ecotoxicity in life cycle assessment. Environ. Toxicol. Chem. 36, 492-500. doi:10.1002/etc.3542.

National Library of Medicine, 2018, Household Products Database. http://householdproducts.nlm.nih.gov, 30-June-2018.

Ozutsumi, K., Abe, Y., Takahashi, R., Fshiguro, S., 1994. Chloro and bromo complexation of the manganese(II) ion and solvation structure of the manganese(II), iron(II), cobalt(II), nickel(II), copper(II), and zinc(II) ions in hexamethylphosphoric triamide. J. Phys. Chem. 98, 9894-9899. doi:10.1021/j100090a025.

Pennington, D.W., Margni, M.D., Ammann, C., Jolliet, O., 2005. Multimedia fate and human intake modeling: Spatial versus nonspatial insights for chemical emissions in Western Europe. Environ. Sci. Technol. 39, 1119-1128. doi:10.1021/es034598x.

Rabesandratana, T., 2016. A crystal ball for chemical safety. Science 351, 651-651. doi:10.1126/science.351.6274.651.

Rabus, R., Hansen, T.A., Widdel, F., 2013. Dissimilatory sulfate- and sulfur-reducing prokaryotes, in: Rosenberg, E., DeLong, E.F., Lory, S., Stackebrandt, E., Thompson, F. (Eds.), The Prokaryotes: Prokaryotic Physiology and Biochemistry. Springer Press, Berlin, Heidelberg, pp. 309-404.

Redman, A., Santore, R., 2012. Bioavailability of cyanide and metal-cyanide mixtures to aquatic life. Environ. Toxicol. Chem. 31, 1774-1780. doi:10.1002/etc.1906. 
Research and Markets, 2018. Hydrogen Cyanide (HCN): 2018 World Market Outlook and Forecast up to 2022. Merchant Research and Consulting Ltd., Dublin, Ireland, p. 52.

Ring, C.L., Arnot, J., Bennett, D.H., Egeghy, P., Fantke, P., Huang, L., Isaacs, K.K., Jolliet, O., Phillips, K., Price, P.S., Shin, H.-M., Westgate, J.N., Setzer, R.W., Wambaugh, J.F., 2019. Consensus modeling of median chemical intake for the U.S. population based on predictions of exposure pathways. Environ. Sci. Technol. 53, 719-732. doi:10.1021/acs.est.8b04056.

Rosenbaum, R.K., Bachmann, T.M., Gold, L.S., Huijbregts, M.A.J., Jolliet, O., Juraske, R., Koehler, A., Larsen, H.F., MacLeod, M., Margni, M.D., McKone, T.E., Payet, J., Schuhmacher, M., van de Meent, D., Hauschild, M.Z., 2008. USEtox - The UNEP-SETAC toxicity model: Recommended characterisation factors for human toxicity and freshwater ecotoxicity in life cycle impact assessment. Int. J. Life Cycle Assess. 13, 532-546. doi:10.1007/s11367-008-0038-4.

Rumble, J., 2018. CRC Handbook of Chemistry and Physics, 99th Ed. CRC Press, Taylor and Francis Group, Boca Raton, Florida.

Schwarzenbach, R.P., Gschwend, P.M., Imboden, D.M., 2016. Environmental Organic Chemistry, 3rd Ed. John Wiley and Sons, Inc., New York.

Shin, H.-M., Ernstoff, A.S., Arnot, J.A., Wetmore, B., Csiszar, S.A., Fantke, P., Zhang, X., McKone, T.E., Jolliet, O., Bennett, D.H., 2015. Risk-based high-throughput chemical screening and prioritization using exposure models and in vitro bioactivity assays. Environ. Sci. Technol. 49, 6760-6771. doi:10.1021/acs.est.5b00498.

Strempel, S., Scheringer, M., Ng, C.A., Hungerbühler, K., 2012. Screening for PBT chemicals among the "Existing" and "New" chemicals of the EU. Environ. Sci. Technol. 46, 5680-5687. doi: $10.1021 / \mathrm{es} 3002713$.

Swedish Chemicals Agency, 2014. Chemicals in textiles - Risks to human health and the environment. Stockholm, p. 142.

Tarasova, N., Makarova, A., Fantke, P., Shlyakhov, P., 2018. Estimating chemical footprint: Contamination with mercury and its compounds. Pure Appl. Chem. 90, 857-868. doi:10.1515/pac-2017-1102.

van Zelm, R., Huijbregts, M.A.J., van de Meent, D., 2009. USES-LCA 2.0 - a global nested multi-media fate, exposure, and effects model Int. J. Life Cycle Assess. 14, 282-284. doi:10.1007/s11367-009-0066-8.

Verougstraete, V., 2018. Risk Management of Complex Inorganic Materials: A Practical Guide. Academic Press, London.

Villars, P., Cenzual, K., Gladyshevskii, R., 2017. Handbook of Inorganic Substances. Walter de Gruyter, Berlin.

Wambaugh, J.F., Setzer, R.W., Reif, D.M., Gangwal, S., Mitchell-Blackwood, J., Arnot, J.A., Jolliet, O., Frame, A., Rabinowitz, J., Knudsen, T.B., Judson, R.S., Egeghy, P., Vallero, D., Cohen Hubal, E.A., 2013. High-throughput models for exposure-based chemical prioritization in the ExpoCast project. Environ. Sci. Technol. 47, 8479-8488. doi:10.1021/es400482g. 
709 Wetmore, B.A., Wambaugh, J.F., Ferguson, S.S., Sochaski, M.A., Rotroff, D.M., Freeman, 710 K., Clewell, H.J., Dix, D.J., Andersen, M.E., Houck, K.A., Allen, B., Judson, R.S., Singh, R., 711 Kavlock, R.J., Richard, A.M., Thomas, R.S., 2012. Integration of dosimetry, exposure, and 712 high-throughput screening data in chemical toxicity assessment. Toxicol. Sci. 125, 157-174. 713 doi:10.1093/toxsci/kfr254.

Woutersen, M., Beekman, M., Pronk, M.E.J., Muller, A., de Knecht, J.A., Hakkert, B.C., 716 2018. Does REACH provide sufficient information to regulate mutagenic and carcinogenic 717 substances? Hum. Ecol. Risk Assess. doi:10.1080/10807039.2018.1480351. 
Inorganic substances are currently missing in toxicity characterization methods.

A classification overview of inorganic substances is provided as starting point.

Economic and environmental relevance of REACH-registered inorganics was analyzed.

About 90 inorganic substance were identified as high-priority for characterization. 